\title{
Exposição a pesticidas e repercussão na saúde de agentes sanitaristas no Estado do Ceará, Brasil
}

\author{
Pesticide exposure and its repercussion in the health \\ of sanitary agents in the State of Ceará, Brazil
}

\author{
Estelita Pereira Lima ${ }^{1}$ \\ Suziy de M atos Bandeira Lopes ${ }^{1}$ \\ $M$ aria I racema M ariano de A morim ${ }^{2}$ \\ Laura H elena Silva Araújo ${ }^{1}$ \\ Kelly Rose Tavares Neves ${ }^{1}$ \\ Evanira Rodrigues $\mathrm{M}$ aia ${ }^{1}$
}

'U niversidadeFederal do Ceará. Rua Divino Salvador 284, Centro. 63180-000 Barbalha CE. estelitaplima@hotmail.com ${ }^{2}$ Fundação $\mathrm{N}$ acional de Saúde.
Abstract Sanitary agents are the most exposed ones to the effects of insecticides in eradication campaigns since its preparation until its application inside and outside houses. The lack of protection equipment and misinformation on how to use the material properly increase the risk of intoxication. The aim of this work was to analyze the occupational history of vector control sanitary agents in Ceará State, Brazil and its effects on their health. Individual recorded interviews were done with 10 agents who verbally described their life history. The content of these interviews were analyzed through the following categories: agent profile, endemic controls, work conditions, risks and health changes. Health risk situations were described from acute and chronic intoxication to problems with alcoholism. The research showed that sanitary agents have been di srespected as human beings as well as their labor rights, showing negligence by their employers.

Key words O ccupational exposure, Insecticides exposure, Vector control
Resumo Osagentes sanitaristas são os trabal hadores mais expostos aos efei tos dos inseticidas nas campanhas antivetoriais, desde o preparo da calda até a aplicação nas áreas intra ou peridomiciliares. Fatores como falta de equipamentos de proteção individual ou desconhecimento da forma correta de manipulação de cada produto aumentam os riscos de intoxicação. 0 objetivo deste trabalho foi analisar a história ocupacional deagentes sanitaristas sobre o controle dos vetores no Estado do Ceará esua repercussão na saúde destes trabalhadores. As histórias de vida ocupacionais foram relatadas por dez agentes, através de entrevistas individuais gravadas. 0 conteúdo foi analisado a partir da construção de categorias como: perfil dos agentes, controle de endemias, condições de trabal ho, riscos e alterações na saúde. Os depoimentos revelaram condições de trabal ho ge radoras de risco à saúde dos agentes, desde intoxicações agudas a crônicas, além de outros problemas, como o al coolismo. Constatou-se que os profissionais foram desrespeitados como seres humanos eque houve descumprimento dos di reitos trabalhistas, evidenciando-se o descaso por parte dos seus superiores e instituição contratante. Palavras-chave Exposição ocupacional, Exposição a inseticidas, Controle de vetores 
Introdução

0 uso de inseticidas para o controle de vetores no Brasil e no Estado do Ceará tem sido intenso desde as campanhas de peste, Chagas, febre amarela, esquistossomose e, ultimamente, de Dengue. Durante essas campanhas, lançou-se mão de todos os grupos químicos de inseticidas: organoclorados, sal inorgânico (cianogás), carbamatos, organofosforados e piretróides.

Alguns produtos destes grupos, como o exaclorobenzeno (BHC) e o cianogás, já foram banidos de campanhas de saúde pública no Brasil, devido ao seu potencial toxicológico para o homem e o ambiente. 0 diclorodifenil tricloroetano (DDT) seacumula nostecidosorgânicos, contaminando as cadeias alimentares, e estudos re velaram efeito cancerígeno em animais de laboratório expostos a esse produto ${ }^{1}$; porém, seu uso ainda é permitido nos programas de controle vetorial.

Os agentes sanitaristas representam a categoria mais exposta aos efeitos dos inseticidas nas campanhas antivetoriais, pois a exposição se dá desde o preparo da calda atéa aplicação nas áreas intra ou peridomiciliares. Os servidores podem absorver esses produtos pelas vias dérmica e aé rea, principalmente entre aqueles que realizam nebulização. Fatores como falta de equipamentos de proteção individual (EPI) ou desconhecimento da forma correta de manipulação de cada produto aumentam os riscos de intoxicação.

No Brasil, a relação entre exposição a inseticidas e efeitos na saúde é bastante investigada entre agricultores. Vários trabalhos realizados internacionalmente e no Brasil têm demonstrado os efeitos nocivos dos agrotóxicos para os agricultores ${ }^{2-4}$. No entanto, os pesquisadores que investigam este problema travam uma luta contra o aparato científico ejurídico instalado junto às grandes corporações industriais do setor químico, que contestam a validade de provas científicas que possam prejudicar o mercado de seus produtos. Outra dificuldade enfrentada referese à epistemologia da toxicologia, que pressupõe a aceitação de padrões, limites e tolerâncias aos resíduos, construídos com base em um suposto "ser humano médio" 5 .

Em relação a agentes sanitaristas na literatura é escassa. Da década de oitenta até 2003 , foram realizadas investigações sobre os níveis de organoclorados no sangue de servidores de $\mathrm{Mi}$ nas Gerais ${ }^{6}, B a h i a^{7}$, São Paulo e M ato Grosso ${ }^{9}$, revelando concentrações, principalmentedeDDT, acima dos níveis estabelecidos pela legislação de saúde ocupacional. Recentemente, no Estado do Pernambuco ${ }^{10}$, um estudo foi conduzido com trabalhadores expostos a organofosforados e a piretróides, com o objetivo de avaliar as alterações auditivas periféricas. Os resultados revelaram que entre os expostos somente aos inseticidas houve $63,8 \%$ de perda auditiva e entre os expostos a inseticida e concomitantemente ao ruído, o agravo foi observado em $66,7 \%$ deles.

Entre os agentes sanitaristas cearenses, muitos manipulam praguicidas há mais de trinta anos, tendo participado de todas as campanhas antivetoriais e expostos a todos os grupos supracitados ${ }^{11}$. No entanto, não há estudos publicados sobre exposição ocupacional a inseticidas neste grupo no Ceará, indicando a necessidade deinvestigar a relação entre a exposição aos inseticidas e sua repercussão na saúde dos agentes.

Para a avaliação desta relação, é necessário o conhecimento do contexto de trabalho em que os agentes estavam ou ainda estão inseridos, através da recapitulação de sua história ocupacional, pois as alterações na saúde dependem de vários fatores que participam da determinação das mesmas, dentre eles os relativos às características químicas e toxicológicas do produto, intensidade da exposição e suscetibilidade do indivíduo ${ }^{12}$.

0 objetivo deste trabalho foi analisar a história ocupacional de agentes sanitaristas sobre 0 controle dos vetores no Estado do Ceará e sua repercussão na saúde destes trabal hadores.

\section{Métodos}

O estudo foi realizado na região do Cariri, local de residência dos sujeitos envolvidos e por ser representativa do Estado do Ceará, quanto à ocorrência de doenças transmitidas por vetores e controladas por meio de inseticidas.

No estudo, foi empregado o método qualitativo história de vida tópica. A história de vida tem como principal função retratar as experiências vivenciadas, bem como as definições fornecidas por pessoas, grupos ou organizações, como esta pessoa, esta organização ou este grupo interpretam sua experiência [...] e a História de Vida Tópica focaliza uma etapa ou um determinado setor da experiência em questão $0^{13}$. Sua validade reside na possibilidade expressa na narrativa que dá forma ao vivido quando os homens elaboram e experimentam a história de sua vida ${ }^{14}$. A escolha deste método deve-se ao objeto em estudo buscar compreender os significados individuais e coletivos do processo saúde-doença, vivenciados 
por agentes sanitaristas expostos a inseticidas, e os métodos qualitativos permitem interpretar os significados erepresentações dos fenômenos partilhados culturalmente pelos grupos sociais.

Atualmente, os estudos qualitativos gozam de reconhecimento, haja vista empregarem mé todos que demonstram "clareza de critérios no julgamento da pertinência do caminho percorrido pelos pesquisadores qualitativistas, desde 0 plano de pesquisa, passando pela coleta de dados, até a interpretação dos resultados"15. Porém, deve ser lembrado que os limites destes estudos estão ancorados na sua impossibilidade de realizar generalizações estatisticamenterepresentativas, sendo sua validade relacionada ao conhecimento original produzido, podendo oferecer a outros pesquisadores hipóteses e possibilidades de novos estudos ${ }^{15,16}$.

Os atores deste estudo foram agentes sanitaristas, que já foram ou ainda são expostos a inseticidas durante suas atividades, e que relataram alguma alteração na saúde, decorrente do uso destes produtos. Esta informação foi coletada durante um estudo piloto realizado anteriormente, em 2005. Nesse estudo, foram detectados trinta agentes que se afastaram das atividades com inseticidas, devido ao surgimento de problemas de saúde ${ }^{11}$. Além destas características, foram considerados como critérios deseleção dos informantes-chave: ter, no mínimo, dez anos de serviço prestados à instituição de trabalho; ter sido ou estar afastado de atividades com inseticidas; apresentar condição intelectual, emocional, médica efísica para participar do estudo eaceitar livre e esclarecidamente participar da pesquisa.

0 instrumento de coleta de dados foi a entre vista aberta. A escolha por esse tipo de entrevista deveu-se à profundidade que a mesma permite, aproximando o pesquisador da essência do objeto em estudo e favorece aos entrevistados falar livremente sobreas experiências vivenciadas.

As entrevistas foram agendadas previamente, no local e horário desejados pel os entrevistados, realizadas individualmente e gravadas, com duração média de sessenta minutos. Durante essas sessões, foram observadas também as expressões físicas e emocionais dos entrevistados e anotadas em diário de campo.

Para atingir o objetivo proposto, foram realizadas dez entrevistas, utilizando-se como crité rio a saturação das falas por recorrência das informações. Estabeleceu-se um corte temporal, partindo do início das atividades com inseticidas até 0 abandono destas, ou até o momento das entrevistas. As falas dos agentes foram transcri- tas, preservando o anonimato dos envolvidos, bem como o nome de pessoas e instituições citadas pelos mesmos. Assim, foi dado a cada agente o nome de um pássaro.

A análise dos dados procedeu ao ordenamento das informações coletadas. As entrevistas foram lidas e agrupadas segundo as categorias de sentido, respeitando os objetivos propostos. Desse modo, constituem-se as categorias de análise: perfil dos agentes; controle de endemias; condições de trabalho e riscos à saúde; alterações na saúde.

A análise da história de vida dos sujeitos foi realizada através da análise do discurso, que visa analisar não só a fala, mas também os sentimentos e expressões demonstradas pelo relator durante a narrativa. Para Bardin ${ }^{17}$, discurso na prática das análises é toda a comunicação estudada não só ao nível dos seus elementos constituintes elementares (a palavra, por exemplo), mas também e, sobretudo a um nível igual esuperior à frase (proposições, enunciados, sequências). [...] 0 discurso não é transposição transparente de opiniões, deatitudes ede representaçõesqueexistam demodo cabal antes da passagem à forma linguageira.

Todos os participantes assinaram um termo de consentimento livre e esclarecido ea pesquisa foi aprovada pelo Comitê de Ética da Universidade Federal do Ceará.

\section{Resultados ediscussão}

\section{Perfil dos agentes}

No passado, os agentes sanitaristas eram conhecidos por guardas. Foram entrevistados agentes que exerciam diferentes funções como guarda de campo, laboratorista eguarda-chefe. A admissão foi feita através de recrutamento e seleção, na qual eles eram avaliados por meio de um teste. Todos eram homens, a maioria casada e jovens no momento da admissão, com 25 anos de idade ou menos. 0 nível de escolaridade nesse período era predominantemente baixo, tendo poucos ingressado na instituição com o ensino médio. Ao iniciarem suas atividades, tornou-se impossível dar continuidade aos estudos, diante do regime de trabalho.

Quase todos os agentes apresentavam mais de vinte anos de trabalho dedicados ao controle vetorial nas campanhas de peste, febre amarela, Chagas, esquistossomose, calazar e dengue, em todo o Estado do Ceará, e alguns atuaram também em outros estados. Atualmente, alguns se 
encontram aposentados ou afastados do contado direto com inseticida.

Naquela época ninguém queria trabalhar nesse trabalho, porque chamava-se de mata rato, era desprezado pelas pessoas (Azulão).

Praticamente tudo que eu aprendi foi depois que eu parei de trabalhar porque, no momento, eu era praticamente analfabeto. Eu parei de estudar, eu optei mesmo pra ajudar meu pai, sabe? Por incrível que pareça, eu tô concluindo $02^{\circ}$ grau agora, com 54 anos de idade (Pintassilgo).

As características dos agentes, especialmente no período de ingresso na instituição de trabaIho, revelam que se tratava de trabal hadores vulneráveis à aquisição de danos à saúde. Além de serem jovens, possivelmente despreparados para a vida, possuíam baixa escolaridade, o que limitava a percepção do grau de periculosidade queo trabalho ofereceria.

\section{Controle de endemias}

Desde a década de quarenta, o controle vetorial e de outras espécies consideradas pragas no Brasil éfeito principalmente por meio de praguicidas. 0 primeiro deles foi o organoclorado DDT para o controle do Aedes aegypti, durante a campanha da febre amarela, vindo a ser substituído posteriormente por outros grupos de inseticidas: organ ofosforados, carbamatos e piretróides ${ }^{18}$.

Segundo os agentes entrevistados, foram usados diversos tipos de formulações químicas para o controle de endemias no Ceará, destacando-se: cianogás, DDT, BHC, bailucid, abate, k-othrine, malathion, cipermetrina eoutros pertencentes aos mesmos grupos. Essa estratégia de controle permitiu que os agentes fossem expostos a múltiplas formulações químicas e de forma prolongada.

0 controle do barbeiro naquela época era através de pulverização das casas. Trabalhei com BHC numa faixa de mais de dez anos e esse BHC foi proibido. D epois eu trabalhei com muitos produtos, o k-othrine, cipermetrina e outra série de produtos (Bem-te-vi).

No combate à malaria, eu trabalhei com 0 $D D T$, no combateà peste eu trabalhei com o DDT a $75 \%$ e o cianogás. No combate à dengue, eu trabalhei com malathion, abate, sidion, com vários produtos. 0 pior não era nem o DDT a 75\%, era outro produto que era usado pra se combater 0 rato na toca, tipo uma bomba de encher pneu de bicicleta, enesse produto tinha o cianogás, um produto altamentetóxico, quehoje se sabea gravidade do produto, na época não se sabia (Pintassilgo).

Quando eu entrei, eu fui trabalhar com um produto chamado bailucid, que hoje não existe mais, foi proibido. Nós trabalhávamos com este bailucid para matar os caramujos, mas antes de matar os caramujos, matava os peixes, qualquer ser que vivia dentro d'água (Patativa).

As falas demonstram que a exposição ocupacional a diferentes agentes tóxicos ocorreu sem que os mesmos tomassem conhecimento da toxicidade dos produtos. Apenas com a proibição imposta pelas agências sanitárias é que os mesmos tomaram conhecimento dos riscos ocupacionais aos quais estavam expostos.

Em trabalho de revisão feito por D'amato ${ }^{19}$, embora o uso de DDT e demais organoclorados tivesse sofrido restrição no Brasil a partir de 1971, o emprego deles continuou a ser permitido nas campanhas de saúde pública (malária e leishmaniose) e o uso emergencial na agricultura. Em anos mais recentes, debatedores da Organização Mundial de Saúde discutiram sobre a proibição do DDT, baseados na associação entre uso de DDT e câncer humano, bem como de DDT no leite materno; concluíram que não havia provas suficientes de seus efeitos à saúde humana, após aplicação em interiores domiciliares, não havendo justificativa de ordem toxicológica ou epidemiológica para modificar a política de controle vetorial, através de aspersão no interior de residências. Isto significa que os trabalhadores continuarão a se expor ao DDT e, por sua vez, mais níveis do produto se acumularão no ambiente.

\section{Condições de trabalho e riscos à saúde}

Alguns agentes afirmaram ter recebido treinamento antes de iniciarem o combate aos vetores através de praguicidas. No entanto, esta afirmação não foi comum a todos. Segundo eles, 0 treinamento era simplesmente operacional e de conduta, ou seja, restringia-se ao preparo e aplicação dos inseticidas e ao comportamento, que se espelhava nas campanhas de guerra. Havia dentro da instituição tratamentos diferenciados para cada cargo dentro de um sistema hierárquico. N as falas dos agentes, quando eles se referem a "eles", estão falando dos seus superiores, guardas-chefes, supervisores e outros. Nenhum agenterelatou ter recebido orientação quanto aos riscos para a saúde. Percebeu-se pelas falas e expressões que a orientação tinha cunho de ordem e não de informação ou cuidado, o que gerava um aumento no risco de intoxicações pelos produtos usados. Essa falta de informação nessa categoria também foi observada por outros autores, ao constatarem que a grande maioria pos- 
sui nível de escolaridade baixa, não permitindo a realização de leitura ou compreensão das instruções dos rótulos das embalagens ${ }^{7}$.

O sinstrutores não orientavam nada como usar equipamentos de segurança. Nós mesmos que tinha que ter cuidado em si mesmos, tinha treinamento adequado sobre aplicação de inseticida, nas paredes, os retoques, mas sobre as orientações dos cuidados, não tinha. $M$ uitas vezes a gente estava fazendo uma borrifação e o vento vinha ebanhava a gente todinho (Sabiá).

Todo mundo sabe que o abate é tóxico, na embalagem fala que é tóxico e eles falavam que isso aqui não faz mal: "Sevocês chegarem em uma casa que alguém for falar que não vai deixar botar na caixa d'água porque faz mal, vocêdiga quenão faz mal" (Canário).

A diferença do nosso trabalho pro regime militar era muito pouco. A diferença era que a gente usava inseticida e eles usam bala, fuzil, essas coisas (Pintassilgo).

No passado, as campanhas eram feitas em forma de jornada, que se prolongavam por um mês ou mais na zona rural. 0 deslocamento no campo era feito a pé, de uma residência a outra, e até entre municípios. Os guardas eram responsáveis pelo transporte do material de trabalho e pela providência da alimentação. Assim, todo o material e pertences eram carregados sobre os ombros.

A gente levava o cianogás, 0 inseticida DDT até enquanto el enão fosse usado, e as ratoeiras pra capturar os roedores domésticos e os silvestres nas roças e a bomba. Nessa época, tinha jornada, chegamosa passar até quarenta diasfora. E o inspetor chegava no carro naquela mordomia e nós no pezim né! (Pintassilgo).

Você fazia um deslocamento de mais de légua com a bomba nas costas, uma bolsa de veneno, a bolsa de roupa e um balde. Então você chegava com uma légua vocêestava todo suado....a sua própria roupa enxugava seu próprio corpo com o veneno. A bolsa de inseticida levava umas dez cargas de inseticida, a bomba pesava mais de dez quilos. Acho que era uma faixa de vinte quilos (Sabiá).

Perguntaram em uma reunião por quea gente era privilegiado e andava de carro. Tinha o carro que a gente andava com quarenta ratoeiras cada guarda. A gente pegava carona com os ratos, porque os ratos era quem tinha privilégio e nós não (Beija-flor).

Eles eram carrascos demais. Eu não conto as vezes que eles saíam de carro e a gente saía de pés. Parece que eles eram instruídos para maltratar a gente(Tico-tico).
Segundo os depoentes, a instituição raramente, fornecia EPI, e quando o fazia, era de qualidade ruim, que não oferecia proteção ou em quantidade insuficiente. Além disso, quando havia o desgaste dos equipamentos, não havia reposição.

$\mathrm{Na}$ campanha de Chagas, eu trabalhava com um inseticida muito forte, o BHC. Então, nessa época, não tínhamos proteção nenhuma, não tinha luva, não tinha máscara, nada, era sem nada. Eu fazia uma máscara por minha conta, um saco que eu fazia uma careta, botava na minha cabeça, mas não adiantava porque queimava demais. $\mathrm{A}$ gente tinha uma farda só. Passava uma semana todinha com uma farda só (Bem-te-vi).

Quando ia tomar banho, devido o veneno ficar queimando, a gentenão podia sair de dentro d'água, a genteia tomar banho num açude. 0 veneno ficava queimando, ficava a pele toda irritada, todo me coçando. Eu já tive foi delírio (Beija-flor).

Às vezes, a gente trabalhava sem máscara, sem luva, botava só um pano no nariz porque faltava máscara (Pitiguari).

Houve um movimento aí na saúde do trabaIhador pra que você usasse aquele equipamento de segurança, mas aquilo foi uma coisa quase temporária, que ao passo que aquele equipamento ia se desgastando não tinha uma política de reposição. Quando tinha aquelas máscaras que os filtros se desgastavam, geralmente era muito difícil pra você receber ou trocar a peça de reposição (Pintassilgo).

As condições de risco no trabalho dos agentes parecem não ter sofrido muitas mudanças. Relatos de agentes que estão ainda em plena atividade revelam a falta de proteção para o trabaIhador, especialmente aqueles que sofrem exposição aérea, como os agentes do "fumacê".

Segundo as palavras de um motorista, o EPI que possuía era "só o macacão. Nenhuma luva, nem máscara, nem nada. Quando não tinha ar condicionado no carro, não era todo mundo que aguentava não" (Tico-tico). Essa situação revela o descumprimento da cláusula dos convênios do Programa deErradicação do Aedesaegypti (PEAa) firmados entre estados e municípios, que tratava do comprometimento de garantir aos manipuladores dos inseticidas exames periódicos e EPI ${ }^{20}$.

$A$ falta deEPI éum fato que se repetetambém entre agentes de outras localidades do país. Estudo real izado com trabal hadores do Estado de Pernambuco revel ou quesomente 2,9\% usavam proteção auditiva durante a nebulização ${ }^{10}$. Já em São Paulo, servidores foram avaliados quanto ao ruído provocado pelo desinsetizador costal motorizado e os resultados indicaram a necessidade do uso de dois protetores auriculares para minimi- 
zar os efeitos à saúde auditiva, bem como melhoria na cobertura dos exames audiométricos ${ }^{21}$.

Além do exercício das atividades sem prote ção, os agentes enfrentavam outros problemas no percurso. A dificuldade de conseguir água e alimentação era constante. Geralmente, as refeições dependiam de doações por parte da população. Em períodos deseca ou em regiões pobres, era comum dormir sem jantar ou iniciar os trabalhos no dia seguinte, sem café da manhã.

$N$ aquela época, a gente se alimentava dessa maneira: pedia 0 almoço na casa daquele cidadão, pedia a janta, vocêtinha um certo apoio da população. M asjá negaram refeição. Q uando isso acontecia, a gente dormia sem comer. No outro dia, a alimentação era café, somente o café. Faltou água várias vezes. Aqui no município do A raripe, à noite num tinha água pra gentetomar banho, conseguimos um pouco d'água num barreiro pra fazer a comida; nós mesmos fizemos nossa comida, e pra tomar banho, ninguém tomou não (Sabiá).

Lhejuro, peranteD eus do céu, quemuitas vezes eu fui dormir com fome, sem janta (Asa branca).

As condições em que os agentes eram deixados nas cidades eram precárias. Algumas vezes, eles conseguiam colaboração da prefeitura e montavam os pontos de apoio (PA), que serviam tanto para o estoque do material, quanto de abrigo durante o período da jornada de trabaIho. Desta forma, além do contato com os produtos químicos durante a aplicação, os agentes ainda dividiam o mesmo espaço para estadia.

A gente viajava e conseguia um PA, ponto de apoio, eo pessoal guardava o inseticida etambores de gasolina e outros produtos mais, e a gente dormia juntamente com esses produtos, de lado, embaixo da rede, às vezes servia até de travesseiro, como se dizia (Canário).

No PA, era tudo misturado. Eram sacos, carradas de caminhão de $\mathrm{BHC}$ ea gente dormindo dentro, setenta a oitenta pessoas dormindo dentro de uma casa (Tico-tico).

Vários relatos sobre acidentes de trabalho foram feitos. Acidentes com a bomba de inseticidas eintoxicações eram constantes. M esmo assim, os trabalhadores não possuíam nenhuma assistência, sendo obrigados a continuar trabalhando.

Àsvezes, a bomba estourava. Aí botava a bomba no chão eia consertar. Quando isso acontecia, a gente lavava o rosto com água e continuava o trabalho. Eu ficava tonto, sentia dor de cabeça, insônia, eu num dormia não (Sabiá).

Se tivesse outra roupa na bolsa, trocava, mas se não, trabalhava com as costas queimando igual fogo (Pitiguari).
O processo dehigienização édefundamental importância para minimizar os efeitos dos inseticidas no corpo, pois a maioria deles tem absorção dérmica e as roupas impregnadas aumentam o contato destes com a pele. Percebe-se que os servidores não adotavam hábitos de higiene adequados, pois só se banhavam no final do dia, e quase sempre voltavam a usar a mesma farda no dia seguinte. A Fundação N acional de Saúde (FUNASA) recomenda, em seu manual de normas técnicas, que deve ser evitado contato com inseticida e, se isso acontecer acidentalmente, o local deve ser lavado com água e sabão imediatamente, e o uniforme deve ser trocado. Ainda refere que aqueles que trabal ham com inseticidas ultrabaixo-volume devem lavar diariamente os seus uniformes ${ }^{20}$. $M$ as, segundo os depoentes, 0 cumprimento dessa norma era inviável, pois não havia fardamento suficiente, já que eram doadas duas fardas por ano.

Os familiares, especialmente as esposas, também sofriam com o trabalho dos agentes, pois indiretamente tinham contato com os inseticidas durante a higienização das fardas. Muitos agentes relataram a percepção de reações orgânicas em suas esposas ou reclamações das mesmas.

A minha esposa suportava porque era o jeito. $M$ as o fardamento quando ela lavava que ia engomar, ficava espirrando direto (Sabiá).

Antes ela nunca apresentou não, mas de uns tempos pra cá, ela apresenta uma alergia, começa a coçar, incha, queima a pele dela, inflama mesmo. Às vezes eu fico pensando que pode ter sido consequência desse veneno (Patativa).

A participação da mulher na cadeia de exposição aos inseticidas não tem sido considerada com o mesmo padrão de risco doshomens. N este estudo, sua colaboração se dava na higiene das roupas dos esposos ou filhos, mas há outras situações importantes de serem lembradas. $\mathrm{Na}$ agricultura, muitas mulheres se expõem diretamente aos agrotóxicos durante as borrifações, auxiliando 0 agricultor ao segurar a mangueira do pulverizador, completamente desprotegidas 3 .

\section{Alterações na saúde}

Os agentes sanitaristas relataram diversos problemas de saúde, observados também em outros estudos publicados sobre os riscos da exposição a inseticidas ${ }^{3}, 12$. Foram citados sinais de intoxicação aguda como tonturas, vômitos, desmaios, cefaléia e espirros. Entre os sinais de intoxicação crônica, foram citados alergia respiratória, problemas de pele e alteração no sistema 
nervoso, tais como amnésia e insônia. Outros já se encontram aposentados devido a patologias mais graves, como atrofia cerebelar. Também foi referido a ocorrência de osteoporose, púrpura, câncer, alcoolismo e hipertensão.

Eu só vivia nervoso. Era o inseticida que era demais. Eu acho que é porque atingia demais os nervos. U ma junta médica me afastou do trabalho porqueestava afetando muito a mente, sabe? Quando eu trabalhava com inseticida, eu sentia muita insônia. A partir do momento que seus nervos são atingidos pelo veneno, você não dorme mais não. Agora por último eu fiz um exame edeu diminuição no fêmur e osteoporose (Sabiá).

M eu comportamento na época que usava os produtos era violento. N esse tempo que eu trabaIhei, eu tive umas quinze suspensões por causa de briga com os colegas. Eu já sou aposentado porque eu tive contato com inseticida. Segundo minha aposentadoria, é por atrofia cerebral, amnésia, e eu acho queé por causa do inseticida (Bem-te-vi).

Eu tenho atrofia cerebelar. 0 neurologista fala que foi do veneno (Asa branca).

A exposição prolongada a diversos inseticidas atinge 0 sistema nervoso do ser humano, especialmente aqueles inibidores das colinesterases, como os organofosforados e carbamatos. Estas enzimas são responsáveis pela hidrólise da acetilcolina, um mediador químico da transmissão do impulso nervoso que, em excesso, prejudica seriamente o sistema nervoso. As colinesterases são marcadores biológicos da exposição a organofosforados e carbamatos, pois estando com atividade reduzida, indicam alterações geradas por diversas doenças, entre elas hepáticas, desnutrição, infecções agudas, infarto do miocárdio e alcoolismo, ou por agentes como os citados pesticidas. Assim, é considerada obrigatória a dosagem periódica da colinesterase nos manipuladores de inseticida, devendo ser realizada, no mínimo, a cada seis meses. Porém, a FU NASA definiu que a periodicidade dos exames deveria ser quinzenal e, dependendo do resultado, o trabalhador deveria ser afastado temporariamente ou definitivamente de atividades com inseticidas ${ }^{20}$, o que parece não ter ocorrido em tempo hábil.

Além das colinesterases, alguns organofosforados podem alterar as esterases, sendo a principal delas a neurotoxicoesterase. Esta enzima, quando inibida, pode determinar no homem neuropatia periférica nos membros inferiores por ação neurotóxica retardada, quesurgegeralmente após quinze dias da intoxicação aguda inicial22.

0 malathion foi outro organofosforado amplamente usado nas campanhas antivetoriais eéreconhecidamente tóxico para seres humanos e carcinogênico para animais. Essa situação caracteriza uma condição de risco de exposição múltipla dos agentes sanitaristas que atuam nesses programas e campanhas, aplicando esses produtos no ambiente enos domicílios. Embora os piretróides tenham mecanismos de ação diferente no organismo, também podem alterar 0 sistema nervoso, pois atuam nos receptores dos canais de sódio das membranas das células nervosas, despolarizando-a e promovendo a hiperexcitabilidade nervosa ${ }^{22}$. No entanto, outros agravos podem estar associados ao uso destes inseticidas, como a perda auditiva, observada em trabalhadores de Pernambuco ${ }^{10}$.

Quanto aos organoclorados como o DDT e outros, atuam sobre o sistema nervoso central, resultando em alterações do comportamento, distúrbios sensoriais, do equilíbrio, da atividade da musculatura involuntária edepressão doscentros vitais, particularmente da respiração. Entre outros danos à saúde, podem provocar neuropatias periféricas, inclusive com paralisias, aplasia medular, lesões hepáticas, renais, arritmias cardíacas e dermatoses. Estudos revelaram efeito cancerígeno em animais de laboratório $0^{1}$. Muitas dessas patologias acometeram os servidores, embora não seja possível identificar o agente químico responsável, já que a exposição foi múltipla e prolongada.

Hoje eu sou um homem hipertenso, tomo dois comprimidos por dia há mais de vinte anos, em consequência desse trabalho. E tem outras coisas que outras pessoas que trabalhavam adquiriram pior, doenças renais, outros pegaram até problemas circulatórios, mas tudo, se ligar bem, foi em consequência desse contato com 0 inseticida. A minha herança do serviço público éessa. M asinfelizmente tinha outros colegas que não tiveram a mesma sorte, alguns chegaram atéa contrair o câncer (Pintassilgo).

0 trabalho acabou com minha saúde, hoje eu tenho doença do pânico, tenho depressão, tenho ansiedade, tenho problema depelemuito sério (Beija-flor).

0 que me levou à aposentadoria é porque eu sou hipertenso e tive um problema na perna, essa parteaqui do tornozelo, 0 osso gasto. Foi 0 acúmulo de inseticida (Azulão).

Eu tive um problema de púrpura, eu comecei a ficar com umas manchas roxas pelo corpo e muito doloridas, quase pretas; eu fui para o médico e ele me encaminhou para fazer uns exames, ver como é que estavam as plaquetas - " e vamos torcer para não ser leucemia". Então eu fiz um mielograma 
várias vezes para ver se era, e graças a D eus não era, era só a púrpura.Com o medicamento não teve cura, não deu jeito, as plaquetas eram sempre baixas, eu toda semana fazia 0 exame para ver como estavam as plaquetas e sempre baixas; não deu certo não, eu tive que tirar o baço (Canário).

Quanto ao alcoolismo, os agentes acreditam ser consequência da distância familiar, ausência na convivência diária com seus filhos e suas esposas. H avia naquela época uma crença, que perdura até hoje, bastante disseminada entre aplicadores de inseticidas, sobre o consumo de cachaça para inativar os efeitos indesejados desses produtos.

Eu acho que se você entrevistar cem pessoas aqui, noventa vai dizer que bebiam. Quando terminava o expediente, era uma forma de você se livrar do inseticida. A gente tinha a saudade, a tristeza de você tá abandonado naquelas matas (Tico-tico).

Eu bebia após cada aplicação, bebia cachaça. Talvez a gente bebesse mais porque passava muito tempo fora de casa e aí juntava a saudade. Q uase todos bebiam. Uns ficaram alcoólatras e morre ram. Teveum aí que morreu há uns dois anos, três anos no máximo. Ele morreu na ativa. Vários colegas já morreram. Teve um que não está nem com três meses, foi por causa da bebida. E tem outro que está afastado por causa debebida. Eu mesmo, quando fui ao médico para me aposentar, o médico disse que ou eu parava de beber ou eu tinha seis meses (Bem-te-vi).

Alguns dosmeus colegas ficaram viciados. Teve um viciado que, depois dele morto, a mosca que chegasse a pousar no corpo dele morria. Têm é muitos quejá morreram, da minha época. Juntava a cachaça com inseticida (Sabiá).

As doenças relatadas são de diversos grupos na sua relação com o trabalho. Variam de doenças nas quais o trabalho é causa necessária (doença profissional) àquelas cujo trabalho aumenta a frequência ou desencadeia um processo latente ${ }^{23}$.

É importante salientar que o grupo de agentes entrevistados poderá ser portador de outras patologias não citadas, pois o conhecimento da relação entre o uso de inseticidas e alterações na saúde ainda é pouco conhecido. Sendo assim, há possibilidade demuitas doen ças terem sido ocultadas, por eles não as considerarem como conse quências de sua atividade laboral.
$N$ ão se teve a intenção de apontar os inseticidas como agentes responsáveis pelos agravos relatados, mas os depoimentos dos servidores revelaram condições de trabalho geradoras de risco à saúde dos mesmos, desde quadros de intoxicações agu das a crônicas, além de outros problemas, como alcoolismo. Estas condições não se referem somenteà exposição ocupacional, mas a todo o contexto de trabal ho em que estavam inseridos. M uitas patologias referidas podem ter sido geradas por um conjunto de fatores, desde a exposição aos inseticidas sem os devidos EPI, às condições de trabal ho que contribuíram para fragilizar a saúde dos mesmos, tais como as condições nutricionais, a falta de assistência à saúde, o esforço físico continuado e o consumo de drogas lícitas (álcool e fumo), que podem ter facilitado a absorção dos inseticidas.

Durante os relatos, foram expressos sentimentos de revolta e sofrimento, principalmente em relação à falta de orientação que não receberam no passado, o distanciamento da família eà perda da saúde, mas, ao mesmo tempo, todos tinham orgulho de ter cumprido seu dever com a saúde pública.

Constatou-se que os profissionais foram desrespeitados como seres humanos e o descumprimento dos direitos trabalhistas, evidenciando-se o descaso por partedos seus superiores einstituição contratante. Enquanto promoviam a saúde pública, a deles era esquecida. A pressão psicológica causada e a cobrança pela produção de trabalho colocaram os atores desta história em condições de sofrimento psíquico; eram tratados em muitos momentos mecanicamente e não como pessoas prestadoras de serviço à comunidade.

As condições de trabal ho no controle de endemias atualmente têm sofrido mudanças. As políticas de saúde dos trabalhadores são mais atuantes, mas, por outro lado, existea política de terceirização dos atuais agentes sanitaristas contratados, criando um novo grupo de risco, pois trabalham sem nenhum tipo de seguro de insalubridade e/ou capacitação prévia quanto ao trabalho eexposição ocupacional. A escassez deEPI ainda continua e o uso intensivo de inseticidas também. Portanto, é preciso que sejam criadas novas estratégias de controle vetorial, que não coloquem em risco a saúde dos trabal hadores, 0 meio ambiente e a vida. 


\section{Colaboradores}

EP Lima trabalhou na coleta, transcrição e análise de dados. SM B Lopes e LHS Araújo trabalharam na coleta e transcrição dos dados. M IM Amorim trabal hou na coleta de dados. KRT Neves e $M$ aia ER trabalharam na elaboração metodológica e revisão do texto.

\section{Agradecimentos}

A todos os agentes sanitaristas que participaram dessa pesquisa.

\section{Referências}

1. Organização Pan-Americana da Saúde/Organização Mundial de Saúde. Manual de Vigilância da Saúde de populações expostas a agrotóxicos. Brasília: M inistério da Saúde; 1996.

2. Castro JSM, Confalonieri U. U so de Agrotóxicos no M unicípio de Cachoeiras de M acacu (RJ). Cien Saude Colet 2005; 2:473-482.

3. Araújo AJ, Lima JS, Moreira JC, Jacob SC, S MO, Monteiro MCM, Amaral AM, Kubota A, Meyer A, Cosenza CAN, N eves C, M arkowitz S. Exposição múltipla a agrotóxicos e efeitos à saúde: estudo transversal em amostra de 102 trabalhadores rurais, Nova Friburgo, RJ. Cien Saude Colet 2007; 1:115-130.

4. Silveira MA, Castro VL, Perez MA. Aplicação de indicadores clínicos de exposição na avaliação da saúde da agricultura familiar: o caso de Sumaré, Brasil. Rev Comunicação em agrobusiness \& meio ambiente [periódico na Internet]. 2004 [acessado 2006 jun 15]; 1(1): [cerca de 26 p.]. Disponível em: http://www.agricoma.com.br/revista.htm

5. Sobreira AEG, Adissi PJ. Agrotóxicos: falsas premissas e debates. Cien Saude Colet 2003; 8: 985-990.

6. Franklin $\mathrm{HMOH}$, Peixoto TMAG. Níveis sanguíneos de $\mathrm{HCH}$ em guardas da Sucam sob alto contato com o produto. In: Anais do X Encontro Nacional de Analistas de Resíduos de Pesticidas; 1986. São Paulo: Instituto Adolfo Lutz; 1986.

7. Carvalho WA, Berbert PR, Rocha NVP. Serum levels of organochlorine insecticides in health workers exposed to DDT in public health campaigns at the State of Bahia, Brazil. 2nd International Environmental Chemistry Congress in Brazil; 1987; Salvador, Bahia.

8. Minelli EV, Ribeiro ML. DDT and $\mathrm{HCH}$ residues in the blood serum of malaria control sprayers. Bulletin of Environmental contamination and toxicology 1996; 57:691-696.

9. Dores EFGC, Carbo L, Abreu ABG. Serum DDT in malaria vector control sprays in Mato Grosso State, Brazil. Cad Saude Publica 2003; 19(2):429-437.

10. Teixeira CF, Augusto LGS, Morata TC. Saúde auditiva de trabalhadores expostos a ruído e inseticidas. Rev. Saude Publica 2003; 37(4): 417-423.

11. Lima EP, Lima JB, Araújo LHS, Leandro LA, Marques LM S. Sequelas associadas à exposição a inseticidas em agentes sanitaristas do Cariri. XX Outubro médico; 2005 out 20-22; Juazeiro do Norte, Ceará.

12. Delgado IF, Paumgartten FJR. Intoxicações e uso de pesticidas por agricultores do município de Paty do Alferes, Rio de Janeiro, Brasil. Cad Saude Publica 2004; 20(1):180-186.

13. Cruz Neto 0. O trabalho de campo como descoberta e criação. In: M inayo M SC, organizadora. Pesquisa social: teoria, método e criatividade. Petrópolis: Vozes; 1994. p. 51-66.

14. Delory-M omberger C. Formação e socialização: os ateliês biográficos de projeto. Educ. Pesqui 2006; 32(2):359-371.

15. Turato ER. M étodos qualitativos e quantitativos na área da saúde: definições, diferenças e seus objetivos de pesquisa. Rev. Saude Publica 2005; 39(3):507-514. 
16. Fontanella BJB, Campos CJG, Turato ER. Coleta de dados na pesquisa clínico-qualitativa: uso de entrevistas não dirigidas de questões abertas por profissionais de saúde. Rev Latino-am Enfermagem 2006; 14(5):812-820.

17. Bardin L. Análise de conteúdo. Lisboa: Edições 70; 1995.

18. Franco O. A história da febre amarela no Brasil. Rio de Janeiro: Ministério da Saúde; 1976.

19. D'amato C, Torres JPM, Malm O. DDT (Dicloro difenil tricloroetano): toxicidade e contaminação ambiental - uma revisão. Quím. N ova 2002; 25(6):9951002.

20. Brasil. M inistério da Saúde. Dengue instruções para pessoal de combate ao vetor: manual de normas técnicas. 3a ed. rev. Brasília: M inistério da Saúde; 2001.

21. Vilela RAG, Malagoli ME, Morrone LC. Trabalhadores da saúde sob risco: o uso de pulverizadores no controle de vetores. Rev Produção 2005; 15(2):263-272.

22. Centro de Controle de Intoxicações de Niterói Intoxicações exógenas agudas por carbamatos, organofosforados, compostos bipiridílicos e piretróides [ $\mathrm{pu}$ blicação na Internet]. 2000 mar-abr [acessado 2005 abr 20]; versão 2000 [cerca 40 p.]. Disponível em: http://www.uff.br/ccin.pdf

23. Brasil. M inistério da Saúde. Doenças relacionadas ao trabalho; manual de procedimentos para os serviços de saúde. Brasília: Ministério da Saúde; 2001.

Artigo apresentado em 30/04/2007

Aprovado em 24/07/2007

Versão final apresentada em 19/10/2007 